\title{
PENGUATAN GENERASI MUDA BERBASIS KOMUNITAS (IMPLEMENTASI PROGRAM DI PANTI ASUHAN KAFALATUL YATAMA SEMARANG)
}

\author{
Misbah Zulfa Elizabeth \\ Universitas Islam Negeri (UIN) Walisongo Semarang \\ elly_sholihan@yahoo.com
}

\begin{abstract}
The youth is the holder estafeta human struggle and development. But in reality, not all young people have the opportunity to forge themselves in order to prepare their individual role in their family since his parents died or because of other calamity. Life in the orphanage then to be an option. With a participatory approach this community engagement program aims to find out what the needs of youth in the orphanage, how to plan and implement communitybased programs, and what the results obtained. Results of the program are: (1) there are motivation to be independent, productive, and responsible, (2) the importance of planting the propagation of Islam as well as the awareness of the importance of public speaking to convey the values of Islam, (3) Entrepreneurship is a subject preparation assistance to have creative and productive life and is a determinant aspect of community empowerment, and (4) IT training is a very important training for debriefing subjects beneficiaries.
\end{abstract}

Keywords: Orphanage, Community Empowerment, Kafalatul Yatama

\begin{abstract}
Abstrak
Pemuda adalah pemegang estafet dan pengembangan perjuangan manusia. Pada kenyataannya, tidak semua pemuda memiliki kesempatan menempa diri untuk mempersiapkan peran masing-masing di dalam keluarganya sejak orang tuanya meninggal atau karena bencana lainnya. Hidup di panti asuban menjadi piliban. Dengan pendekatan partisipatif, program keterlibatan masyarakat ini bertujuan untuk. mencari tabu apa kebutuban pemuda di panti asuban, bagaimana merencanakan dan melaksanakan program berbasis masyarakat, dan apa hasil yang diperoleh. Hasil pelaksanaan program adalah: (1) tampak adanya motivasi untuk mandiri, produktif, dan bertanggung jawab, (2) pentingnya penanaman kesadaran akan dakwah Islam serta pentingnya public speaking untuk menyampaikan nilai-nilai Islam, (3) Wirausaba merupakan penyiapan subyek dampingan untuk memiliki jiwa kreatif dan produktif dan merupakan aspek penentu pemberdayaan masyarakat, dan (4) Pelatihan IT merupakan pelatiban yang sangat penting bagi pembekalan subyek dampingan.
\end{abstract}

Kata kunci: Panti Asuhan, Pemberdayaan Masyarakat, Kafalatul Yatama 


\section{Pendahuluan}

Pandangan yang menyatakan bahwa generasi muda merupakan harapan bangsa bukan merupakan pandangan kosong tanpa makna. Andai dapat diasosiasikan dengan pertandingan lari maraton, maka generasi muda merupakan pemegang tongkat estafet dari pelari pemegang tongkat estafet sebelumnya. Sebuah hadits menegaskan: "Subanul yaum rijaalul khad" (Pemuda saat ini adalah pemimpin masa yang akan datang). Oleh karena itu pemuda harus siap untuk memegang tongkat estafet itu dengan baik sehingga dapat menyerahkan kepada pelari sesudahnya ketika saatnya tiba.

Merefleksi dari analog di atas tampak bahwa penggantian generasi untuk melanjutkan perjuangan dan khidmah kepada masyarakat tidak dapat dilakukan tanpa perencanaan serta perjuangan yang sungguh-sungguh. Hal ini karena pembangunan manusia bukan persoalan yang mudah. Berbagai persoalan harus dihadapi, termasuk di dalamnya persoalan budaya. Inilah yang dialami dalam proses penyiapan remaja putri dalam kerangka pemberdayaan masyarakat.

Lokus dari program Karya Pengabdian ini adalah di Panti Asuhan Putri Kafalatul Yatama Yayasan Masjid Attaqwa Perumahan Ngaliyan Indah. Lokasi perumahan ini berada di wilayah Kelurahan Ngaliyan, Kecamatan Ngaliyan Kota Semarang Jawa Tengah. Secara historis Panti Asuhan Putri (PAP) Kafalatul Yatama Yayasan Masjid AT-Taqwa merupakan pantiasuhan yang diinisiasi oleh jamaah masjid At-Taqwa, atau lebih tepat prakarsa dari bidang Sosial Ekonomi Ta'mir Masjid At-Taqwa Ngaliyan Indah. Gagasan pendirian panti asuhan berangkat dari kepedulian terhadap masyarakat yang kurang mampu, khususnya yatim piatu dalam hal masa depan mereka. Sambutan masyarakat cukup menggembirakan. Diawali adanya lahan wakaf seluas $200 \mathrm{~m}^{2}$, dan kesediaan pemberi wakaf memberi kesempatan kepada masyarakat untuk turut berwakaf dengan membeli tanah tambahan, maka dalam waktu singkat Ta'mir Masjid At-Taqwa berhasil menyediakan lahan total seluas $600 \mathrm{~m} 2$ untuk tempat berdirinya panti asuhan. Adapun lokasi Panti Asuhan Putri Kafalatul Yatama adalah di Jl. Bukit Panembahan Senopati RW 03 Kelurahan Ngaliyan Kecamatan Ngaliyan. Pada hari Selasa tanggal 
6 Desember 2011 gagasan mulia tersebut diwujudkan dengan diresmikannya Panti Asuhan Kafalatul Yatama. Kepengurusan Panti Asuhan ini berada di bawah naungan Yayasan Masjid At-Taqwa Ngaliyan Indah RW 03 Kelurahan Ngaliyan Kecamatan Ngaliyan Kota Semarang. Bangunan Panti Asuhan saat ini belum selesai pembangunannya, namun kegiatan panti asuhan telah dimulai. Sebelumnya aktifitas panti menempat di sebuah rumah milik jamaah masjid yang berlokasi di Jl. Karonsih Utara Raya No. 325 Telp. (024) 7607466. Namun demikian sejak 22 Desember 2014 panti ini telah menempati bangunan panti yang belum sepenuhnya jadi.

Panti Asuhan Kafalatul Yatama saat ini menampung empat belas orang anak asuh pada jenjang pendidikan Sekolah Dasar (SD Muhammadiyah Pusponjolo sebanyak 2 anak), MTs ( MTs Nurul Islam sebanyak 4 anak) dan SMK (SMK Muhammadiyah Boja sebanyak 8 anak). Empat belas orang anak asuh, sebagaimana generasi muda lainnya, sebagai remaja putri sudah semestinya mendapatkan pendidikan yang menjadi hak mereka sehingga selain pendidikan formal, mereka juga dipersiapkan sebagai generasi yang memiliki aqidah dan keberagamaan yang baik, serta memiliki ketrampilan (soft-skill) untuk mendukung kehidupan mereka di masa yang akan datang.

\section{Panti Asuhan dalam Pengasuhan Anak Yatim}

Secara konseptual panti asuhan anak adalah suatu lembaga usaha kesejahteraan sosial yang mempunyai tanggung jawab untuk memberikan pelayanan kesejahteraan sosial pada anak terlantar dengan melaksanakan penyantunan dan pengentasan anak terlantar, memberikan pelayanan pengganti orang tua/wali anak dalam memenuhi kebutuhan fisik, mental dan sosial kepada anak asuh sehingga memperoleh kesempatan yang luas, tepat dan memadai bagi pengembangan kepribadiannya sesuai dengan yang diharapkan sebagai bagian dari generasi penerus cita-cita bangsa dan sebagai insan yang akan turut serta aktif dalam bidang pembangunan nasional (Depsos RI, 2004: 4).

Panti asuhan merupakan suatu lembaga yang sangat populer untuk membentuk perkembangan anak-anak yang tidak memiliki 
keluarga ataupun yang tidak tinggal bersama dengan keluarga. Anakanak panti asuhan diasuh oleh pengasuh yang menggantikan peran orang tua dalam mengasuh, menjaga dan memberikan bimbingan kepada anak agar anak menjadi manusia dewasa yang berguna dan bertanggung jawab atas dirinya dan terhadap masyarakat di kemudian hari (Santoso, 2005).

Panti asuhan merupakan salah satu lembaga perlindungan anak yang berfungsi untuk memberikan perlindungan terhadap hak-hak anak (Pedoman Perlindungan Anak, 1999). Pada umumnya, panti asuhan di kota-kota besar berusaha mengatasi permasalahan-permasalahan sosial yang terjadi pada anak dimana panti asuhan tersebut menampung anakanak yang mengalami berbagai permasalahan (Muchti, 2000). Gospor Nabor (Bardawi, 1999:5) menjelaskan bahwa: "Panti asuhan adalah suatu lembaga pelayanan sosial yang didirikan oleh pemerintah maupun masyarakat, yang bertujuan untuk membantu atau memberikan bantuan terhadap individu, kelompok masyarakat dalam upaya memenuhi kebutuhan hidup". Dari beberapa pengertian panti asuhan di atas dapat disimpulkan bahwa panti asuhan merupakan sebuah lembaga pengganti fungsi orang tua bagi anak-anak terlantar dan memiliki tanggung jawab dalam memberikan pelayanan kesejahteraan sosial bagi anak-anak terlantar terutama kebutuhan fisik, mental, dan sosial pada anak asuh supaya mereka memiliki kesempatan untuk mengembangkan diri dan menjadi generasi penerus cita- cita bangsa dan sebagai insan yang akan turut serta dalam bidang pembangunan sosial.

Dalam Islam perintah untuk memelihara anak yatim ditegaskan di dalam Al-Qur'an di beberapa ayat. Allah menyebutkan urusan anak yatim sebanyak 22 kali. Berkenaan dengan ayat-ayat tentang anak yatim tersebut, setidaknya ada 3 hal penting yang harus diperhatikan yaitu ihsan (berbuat baik) kepada anak yatim, hak-hak anak yatim, dan harta anak yatim. Meskipun anak yatim kehilangan kasih sayang orang tuanya, tetapi tidak berarti harus kehilangan kasih sayang dalam hidupnya. Perintah Islam kepada kaum muslim untuk memberikan perhatian besar kepada anak yatim merupakan jalan bagi anak yatim untuk mendapatkan kasih sayang itu. Berikut adalah beberapa landasan untuk berbuat baik kepada anak yatim: 


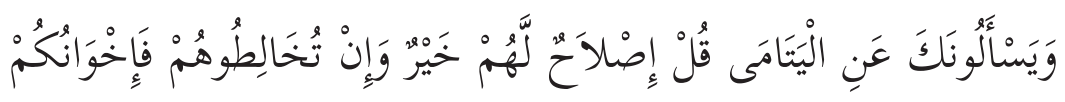

Dan mereka bertanya kepadamu tentang anak yatim, katakalah: "Mengurus urusan mereka secara patut adalah baik, dan jika kamu bergaul dengan mereka, Maka mereka adalah saudaramu" (Al-Baqarah: 220)

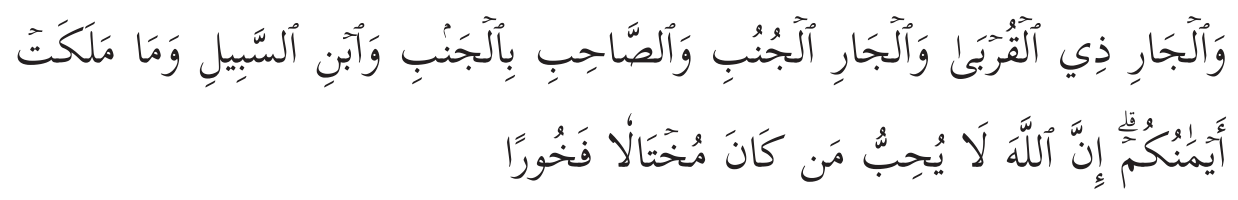

"Sembahlah Allah dan janganlah kamu mempersekutukanNya dengan sesuatupun, dan berbuat baiklah kepada dua orang ibu-bapa, karib-kerabat, anak-anak yatim, orang-orang miskin, tetangga yang dekat dan tetangga yang jauh, dan teman sejawat, ibnu sabil dan hamba sahayamu. Sesungguhnya Allah tidak menyukai orang-orang yang sombong dan membanggabanggakan diri." (An-Nisa': 36)

Islam mengharuskan agar anak yatim mendapatkan kasih sayang, kelembutan, dan pendidikan baik yang dapat membentuknya menjadi manusia shaleh dalam kehidupannya. Berkenaan dengan hal tersebut, berkait dengan kehidupan Nabi Muhammad yang yatim, disebutkan di dalam al-Qur'an:

$$
\text { أَلَمْ يَجِدْكَ يَتِيماً فَاوَى }
$$

"Bukankah Dia mendapatimu sebagai seorang yatim, lalu dia melindungimu? Dan Dia mendapatimu sebagai seorang yang bingung, lalu dia memberikan petunjuk. Dan Dia mendapatimu sebagai seorang yang kekurangan, lalu dia memberikan kecukupan." (Adh-Dhuha: 6-8)

Di antara perintah Allah untuk berinfaq untuk anak yatim adalah firmanNya: 


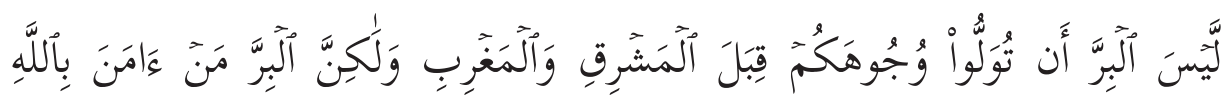

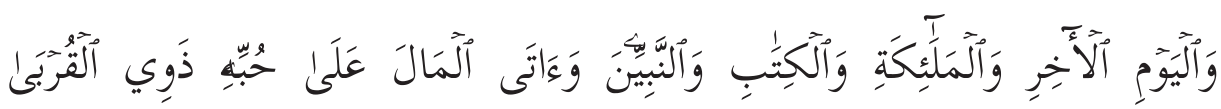

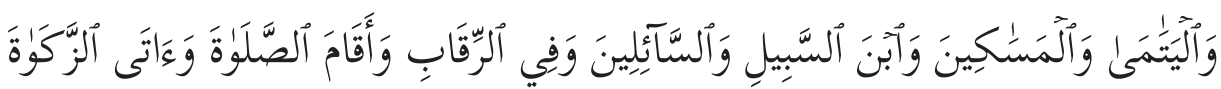

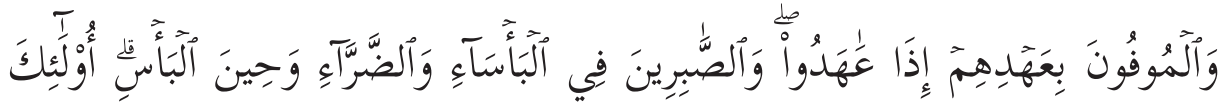

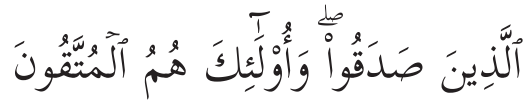

"Bukanlah menghadapkan wajahmu ke arah timur dan barat itu suatu kebajikan, akan tetapi sesungguhnya kebajikan itu ialah beriman kepada Allah, hari kemudian, malaikat-malaikat, kitab-kitab, nabi-nabi dan memberikan harta yang dicintainya kepada kerabatnya, anak-anak yatim, orang-orang miskin, musafir (yang memerlukan pertolongan) dan orang-orang yang meminta-minta; dan (memerdekakan) hamba sahaya..." (AlBaqarah: 177)

Kemuliaan orang-orang yang mengasuh, dan memelihara anak yatim juga disebutkan dalam banyak hadits Nabi Muhammad Shallallahu 'Alaihi Wasallam. Di antara sabda-sabdanya, beliau menjamin orang-orangyang mengikuti sunnahnya dalam menyantuni anak yatim dengan surga:

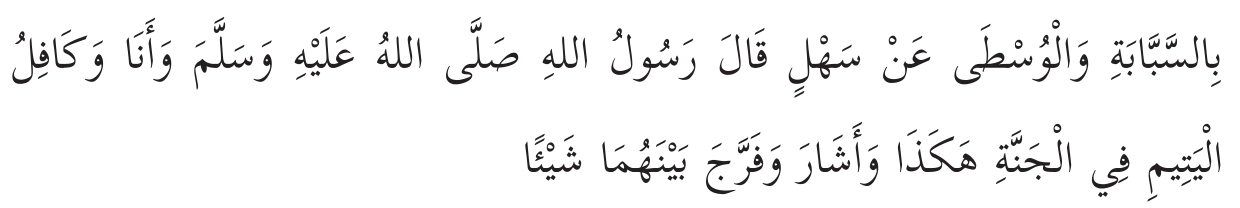

Diriwayatkan dari Sahl, Rasulullah saw bersabda: "Aku dan pemelihara anak yatim, di surga seperti ini." Lalu beliau mengisyaratkanjaritelunjukdanjaritengahdan merenggangkan di antara keduanya sedikit. (HR. Al-Bukhari). 


\section{Alasan Memilih Subyek Dampingan}

Pemilihan Panti Asuhan Putri Kafalatul Yatama Masjid At-Taqwa sebagai lembaga dampingan, didasarkan beberapa alasan, yaitu: (1) Secara geografis panti ini berada di wilayah pinggiran kota dengan hunian berupa perumahan sehingga menarik untuk diamati dan dilakukan proses pendampingan; (2) Secara sosial ekonomi, komunitas di mana panti tersebut berada merupakan komunitas kelas menengah hingga menengah atas, dengan pekerjaan pegawai, baik di lembaga pemerintahan, BUMN, maupun swasta; (3) Keberadaan panti ini menarik karena sebagai lembaga sosial, panti ini berbasis komunitas. Maksudnya adalah bahwa Panti Asuhan Putri Kafalatul Yatama didirikan atas inisiatif komunitas warga muslim RW III Kelurahan Ngaliyan Kecamatan Ngaliyan Semarang; (4) Panti ini dikhususkan bagi anak dan remaja perempuan dari kalangan yatim dan dhuafa.

Dengan beberapa pertimbangan di atas, dalam kerangka pemberdayaan remaja putri, pemberdayaan dalam makna yang sesungguhnya, menjadi point yang perlu ditegaskan dalam hal ini. Remaja putri yang menjadi subyek binaan adalah anak-anak remaja perempuan dengan kondisi yatim dan dhuafa, sementara komunitas yang mendukung (supporting community) adalah komunitas menengah ke atas. Perpindahan hidup anak-anak dari kondisi dan lingkup keluarga yang sederhana ke dalam komunitas pendukung yang berbeda perlu untuk mendapatkan perhatian, baik terkait aspek spiritualitas, emosional, maupun intelektual.

Permasalahan yang terkait dengan kesenjangan budaya (cultural lag), dan orientasi pemberdayaan remaja putri harus menjadi perhatian. Oleh karena itu dalam pelaksanaan program komunitas dibekali materi-materi pendukung agar menambahkan motivasi berprestasi dan kemandirian untuk para remaja putri itu, dengan kerangka imaje diri (self image) sebagai muslimah yang produktif, kreatif dan mandiri.

\section{Kondisi Dampingan Saat Ini}

Sebagai sebuah panti asuhan, PAP Kafalatul Yatama merupakan panti dengan sistem pelayanan melalui kegiatan terkonsentrasi di dalam 
panti atau di dalam asrama. Dalam melaksanakan kegiatannya panti diharapkan dapat menerapkan memakai sistematika dan metode pekerja sosial sistem panti. Penanganan anak yatim melalui panti merupakan alternatif terakhir. Apabila penanganan anak yatim di lingkungan asal "mengkhawatirkan" bagi perkembangan anak, dan pendidikan melalui panti dipandang lebih baik dan mudah maka pilihan pendidikan di panti dapat dilakukan.

Melalui sistem panti ini diharapkan anak mampu mengembangkan kemampuan yang ia miliki, karena dalam perkembangan seorang anak diharapkan semua kebutuhan anak dapat terpenuhi, sehingga perkembangan anak menjadi optimal. Dalam melaksanakan fungsinya, lembaga panti asuhan harus berusaha semaksimal mungkin untuk menciptakan suasana dan pola kehidupan seperti di dalam sebuah keluarga pada umumnya.

Kondisi ini dimungkinkan terjadi di PAP Kafalatul Yatama karena dasar pertimbangan (basic consideration) didirikannya panti ini adalah perintah agama, dengan lembaga yang menaungi adalah yayasan masjid, yaitu Yayasan Masjid At-Taqwa. Oleh karena itu, dalam perspektif dasar pendirian PAP Kafalatul Yatama telah memiliki landasan religius dan filosofi yang kuat. Namun demikian, untuk tercapainya tujuan maka proses pencapaian itu juga penting untuk dipertimbangkan. Dengan supporting community yang kuat maka tawaran kemitraan komunitas (community engagement) harus dilaksanakan. Untuk tujuan itulah program pemberdayaan ini menjadi penting.

Permasalahan pokok yang akan menjadi titik perhatian dalam program Karya Pengabdian Dosen dengan tema "Pemberdayaan Remaja Putri Melalui Kemitraan Komunitas ini adalah bagaimana upaya untuk memberikan stimulan pendidikan remaja putri di PAP Kafalatul Yatama agar mereka dapat menjadi muslimah yang taat, kreatif, produktif, dan mandiri. Untuk tujuan itu permasalahan yang ingin diselesaikan dalam karya pengabdian dosen dapat dirinci sebagai berikut:

1. Bagaimana upaya untuk menggugah dan meningkatkan semangat keagamaan di kalangan remaja putri, 
2. Bagaimana upaya untuk menumbuhkan kesadaran sebagai remaja putri muslim dalam perannya di dalam masyarakat,

3. Bagaimana upaya untuk menumbuhkan kesadaran arti penting pendidikan ketrampilan untuk orientasi kewirausahaan, dan

4. Bagaimana upaya untuk menumbuhkan kesadaran arti penting penguasaan IT.

Dengan tujuan program sebagaimana disebutkan di atas maka program pemberdayaan masyarakat dengan subyek dampingan Panti Asuhan Putri Kafalatul Yatama Masjid Attaqwa ini diharapkan dapat mempersiapkan remaja putri di Panti Asuhan Kafalatul Yatama Masjid Attaqwa sebagai generasi muslim penerus yang memiliki kesadaran akan perannya di masa yang akan datang. Untuk itu aspek-aspek yang ingin dijawab dari permasalahan di atas merupakan aspek yang menjadi parameter kesiapan remaja putri di PAP Kafalatul Yatama Masjid Attaqwa.

Untuk tujuan tersebut dilakukan proses penjalinan kemitraan dengan komunitas di mana panti itu berada, yaitu komunitas RW III Kelurahan Ngaliyan Kecamatan Ngaliyan. Pola kemitraan dalam pemberdayaan remaja putri di panti ini ditujukan bagi peningkatan peran serta komunitas dalam program kesejahteraan yang telah dicanangkan oleh undang-undang. Peran serta dan partisipasi komunitas akan memunculkan dukungan dan keterlibatan dalam kerangka kemajuan panti, yang implikasinya adalah pengembangan generasi muda yang disuh di dalam panti. Adapun parameter keberhasilan program ditetapkan sebagai berikut: (1) Pelaksanaan aktifitas keagamaan secara lebih baik, (2) Keberanian untuk tampil di hadapan publik, (3) Menunjukkan hasil kreatifitas berupa ketrampilan yang diinginkan dalam need assesment.(4) Menunjukkan kemampuan membuat desain karya menggunakan program komputer, sesuai yang telah dinyatakan dalam need assesment.

Di sisi komunitas, pada akhir program semakin tampak keterlibatan serta partisipasi komunitas dalam berbagai program panti. Peningkatan keterlibatan ini akan tampak dalam kesediaan anggota komunitas untuk bersama-sama pengurus mendampingi subyek binaan dalam proses pendidikan dan pemberdayaan. 


\section{Metode Pengabdian}

Program pemberdayaan masyarakat terkait dengan penguatan generasi muda ini dilaksanakan menggunakan strategi pendekatan partisipatory, yakni pihak dampingan dan pendamping berada dalam posisi yang setara, dampingan bukanlah obyek kajian dan pendamping bukan subyek. Sejak preliminary research telah dilakukan upaya menemukenali permasalahan secara participatory oleh kedua belah pihak, bahkan proses penyusunan tindak lanjut kajian juga dilakukan bersama antar pendamping dan mitra dampingan sebagai bagian dari proses belajar bersama.

Dari strategi tersebut, direncanakan beberapa tahapan atau langkah yang akan ditempuh, yaitu sebagai berikut: (1) Pengumpulan data dan informasi mengenai kondisi subyek. (2) Melakukan analisis (3) Memetakan potensi dan hambatan. (4) Menentukan prioritas program.(5) Monitoring dan Evaluasi. Upaya monitoring dan evaluasi ini dilakukan pada seluruh tahapan program seluruh rangkaian dan proses pemberdayaan itu untuk dinilai sejauh mana keberhasilan dan kegagalannya. Upaya monitoring dan evaluasi secara kontinyu ini memungkinkan terantisipasinya kegagalan program. Monitoring di sisi panti terkait dengan desain program dan subyek program, sementara monitoring dan evaluasi pada sisi materi, desain program, kesiapan, serta penerimaan subyek dampingan. (6) Pelaporan.

Adapun metode yang digunakan dalam pelaksanaan program pengabdian ini meliputi ceramah dan diskusi (penguatan semangat keagamaan dan kehidupan beragama masyarakat PAP Kafalatul Yatama), pelatihan dan workshop (ketrampilan, baik ketrampilan kerajinan tangan maupun IT), penguatan/penambahan sarana prasarana (komputer/laptop, alat jahit menjahit), simulasi (image building), pendampingan, serta monitoring dan evaluasi

\section{Tahapan Pelaksanaan Program Pengabdian}

Program pengabdian yang dilaksanakan di PAP Kafalatul Yatama masjid Attaqwa Ngaliyan Semarang difokuskan pada pemberdayaan remaja putri sebagai subyek program dengan melalui kemitraan komunitas. Pendekatan ini menggambarkan keterpaduan dalam melakukan upaya pemberdayaan remaja putri di PAP Kafalatul 
Yatama Ngaliyan Semarang, yaitu keterpaduan antara subyek program dengan pelaksana program sebagai resource persons.

Terkait dengan pendekatan tersebut, pemberdayaan masyarakat dilakukan melalui dua aspek utama, yaitu pendidikan dan ketrampilan. Pendidikan meliputi pendidikan agama dan kepribadian, dan ketrampilan meliputi ketrampilan dalam pembuatan kerajinan tangan (hadicraft) serta ketrampilan dalam menguasai perangkat IT. Melalui pengembangan kedua aspek utama tersebut diharapkan agar program ini akan memberikan manfaat secara simultan dan timbal balik. Penguatan keagamaan terhadap remaja putri majlis taklim di dalam panti diharapkan akan memberikan dampak religius pada remaja putri. Dengan relijiusitas yang baik disertai dengan pengauatan integritas diri sebagai perempuan akan memunculkan kepribadian muslimah yang kuat sehingga mampu menangani kehidupannya dengan baik. Kehidupan yang baik akan dapat direncanakan jika remaja putri memiliki bekal ilmu dan ketrampilan. Bekal ilmu serta ketrampilam akan melahirkan kekuatan sosial ekonomi masyarakat yang pada gilirannya nanti akan membentuk masyarakat yang sejahtera dan adil.

Secara umum pelaksanaan pemberdayaan masyarakat secara terpaduyang dilaksanakandiPAPKafalatul Yatama melaluipendekatan kemitraan komunitas, dapat digambarkan sebagai berikut:

Sumber: Analisis Data Primer

Gambar 2

Kolaborasi antara Komunitas dengan PAPKY

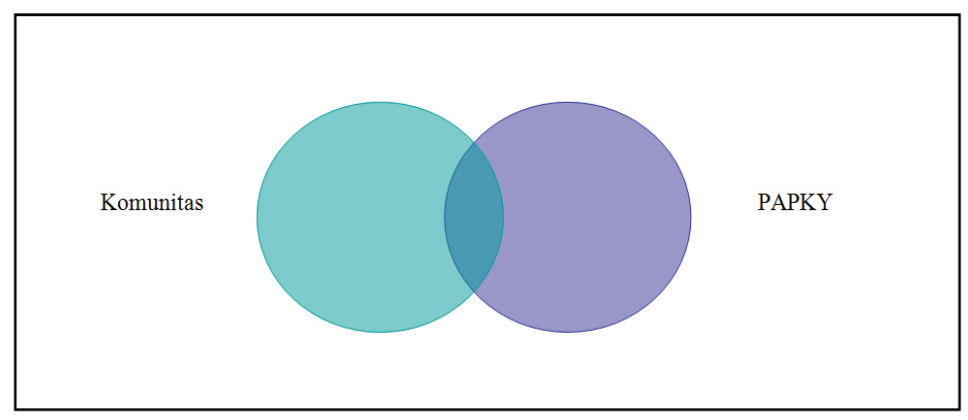


Dari gambar di atas dapat dijelaskan hubungan antara PAP Kafalatul Yatama dengan komunitas. Titik singgung menggambarkan adanya interest yang sama, atau sesuai sehingga memungkinkan pelaksanaan program yang sesuai. Dalam kerangka pengembangan dua aspek tersebut di atas, yaitu aspek pendidikan dan ketrampilan maka pelaksanaan program melalui tahap-tahap sebagai berikut:

\section{Pengumpulan data}

Pada tahap ini pelaksana program (pengabdi) mengawali dengan temu awal dengan komunitas sasaran, yaitu remaja putri yang berada di PAP Kafalatul Yatama untuk menyampaikan maksud dan memberikan gambaran umum program, sekaligus menjajaki kemungkinan dilaksanakannya program pengabdian di PAP Kafalatul Yatama sekaligus mengumpulkan data awal yang diperlukan. Tahap ini dilaksanakan pada bulan September minggu pertama dan dilaksanakan bersama oleh pelaksana pengabdian dan pengasuh panti. Data yang diperoleh tergambar dalam Tabel 1.

Tabel 1

\section{Data Anak Asuh PAP Kafalatul Yatama}

\begin{tabular}{|c|c|c|c|c|}
\hline No & Nama & TTL & Asal & Pendidikan \\
\hline 1 & $\begin{array}{l}\text { Mukti Dian } \\
\text { Ningrum }\end{array}$ & $\begin{array}{l}\text { Grobogan, } 06 \\
\text { Maret } 2000\end{array}$ & Purwodadi & $\begin{array}{l}\text { SMP Nurul Islam } \\
\text { Semarang (Kelas IX) }\end{array}$ \\
\hline 2 & $\begin{array}{l}\text { Anis } \\
\text { Setiyawati }\end{array}$ & $\begin{array}{l}\text { Semarang, } 14 \\
\text { Februari } 1997\end{array}$ & Semarang & $\begin{array}{l}\text { SMP Nurul Islam } \\
\text { Semarang (Kelas IX) }\end{array}$ \\
\hline 3 & Lismiyati & $\begin{array}{l}\text { Demak,02 Mei } \\
1998\end{array}$ & Demak & $\begin{array}{l}\text { SMK Muhammadiyah } 2 \\
\text { Boja (Kelas x PS) }\end{array}$ \\
\hline 4 & Ruainah & $\begin{array}{l}\text { Demak, } 09 \\
\text { Januari } 1997\end{array}$ & Demak & $\begin{array}{l}\text { SMK Muhammadiyah } 2 \\
\text { Boja (Kelas x PS) }\end{array}$ \\
\hline 5 & Ista Kamala & $\begin{array}{l}\text { Demak, } 23 \text { Juni } \\
1998\end{array}$ & Demak & $\begin{array}{l}\text { SMK Muhammadiyah } 2 \\
\text { Boja (Kelas x PS) }\end{array}$ \\
\hline 6 & $\begin{array}{l}\text { Rina } \\
\text { Rochmawati }\end{array}$ & $\begin{array}{l}\text { Kendal, } 13 \\
\text { Agustus } 1998\end{array}$ & Kendal & $\begin{array}{l}\text { SMK Muhammadiyah } 2 \\
\text { Boja (Kelas XI BB) }\end{array}$ \\
\hline 7 & $\begin{array}{l}\text { Rani } \\
\text { Handayani }\end{array}$ & $\begin{array}{l}\text { Kendal, } 04 \\
\text { Februari } 1998\end{array}$ & Kendal & $\begin{array}{l}\text { SMK Muhammadiyah } 2 \\
\text { Boja (Kelas x BB) }\end{array}$ \\
\hline
\end{tabular}




\begin{tabular}{cllll}
\hline 8 & Nur Janah & $\begin{array}{l}\text { Kendal, 16 } \\
\text { Oktober 1998 }\end{array}$ & Kendal & $\begin{array}{l}\text { SMK Muhammadiyah 2 } \\
\text { Boja (Kelas x BB) }\end{array}$ \\
9 & $\begin{array}{l}\text { Hidayatul- } \\
\text { luthfiyah }\end{array}$ & $\begin{array}{l}\text { Demak, 11 Juni } \\
1999\end{array}$ & Demak & $\begin{array}{l}\text { SMK Muhammadiyah 2 } \\
\text { Boja (Kelas x BB) }\end{array}$ \\
10 & $\begin{array}{l}\text { Ratna } \\
\text { Lestari }\end{array}$ & $\begin{array}{l}\text { Magelang,22 } \\
\text { November 1999 }\end{array}$ & Magelang & $\begin{array}{l}\text { SMK Muhammadiyah 2 } \\
\text { Boja (kelas x PS) }\end{array}$ \\
11 & $\begin{array}{l}\text { Dina } \\
\text { Sofianti }\end{array}$ & $\begin{array}{l}\text { Semarang, 10 } \\
\text { Februari 2001 }\end{array}$ & Semarang & $\begin{array}{l}\text { SMP Nurul Islam ( kelas } \\
\text { VII ) }\end{array}$ \\
& $\begin{array}{l}\text { Therryanna } \\
\text { Dewi } \\
\text { Aryanti }\end{array}$ & $\begin{array}{l}\text { Semarang, 23 } \\
\text { Maret 2002 }\end{array}$ & Semarang & $\begin{array}{l}\text { SMP Nurul Islam ( kelas } \\
\text { VII ) }\end{array}$ \\
\hline
\end{tabular}

Sumber: Data PAP Kafalatul Yatama

Tampak dari data di atas bahwa subyek dampingan adalah para remaja putri dengan usia 12 tahun hingga 17 tahun yang merupakan rentang usia remaja. Usia remaja (Surbakti, 2009) secara psikologis merupakan usia pencarian diri sehingga kecenderungannya tampak dalam upaya untuk mencoba-coba sesuatu yang baru serta memberontak. Selain itu juga muncul ciri seperti ingin menunjukkan keberanian, tidak mau diatur, namun menginginkan pengarahan, walaupun kadang-kadang tampak kenekatan pada keputusan yang mereka ambil.

Berdasarkan pertimbangan di atas maka langkah need assesment dalam memulai program pendampingan pemberdayaan remaja putri sangat tepat. Program yang sifatnya top-down bisa jadi akan ditinggalkan oleh subyek dampingan karena tidak sesuai dengan keinginan mereka. Oleh karena itu penjajagan mengenai kondisi dampingan sangat penting dalam konteks ini.

Pada hari yang berbeda, pengabdi menghadirkan tokoh masyarakat dalam komunitas RW III Kelurahan Ngaliyan untuk menyampaikan maksud dan tujuan pengabdian di panti agar mereka merasa handarbeni, peduli, serta terlibat dan bertanggung jawab atas keberlangsungan program serta sustainabilitynya. Hasil dari pertemuan tersebut tampak dalam Tabel 2 di bawah ini: 


\section{Tabel 2}

Potensi Anggota Komunitas

\begin{tabular}{|c|c|c|c|c|}
\hline No & Nama & Alamat & Potensi & Kesediaan \\
\hline 1 & Ibu Teguh & RT 01 & Pendidikan & Bersedia \\
\hline 2 & $\begin{array}{l}\text { Ibu Win Arianto, Ibu } \\
\text { Wid Wahyono }\end{array}$ & RT 02 & $\begin{array}{c}\text { Ketrampilan, } \\
\text { Pendidikan,Tata } \\
\text { Busana, Kepribadian }\end{array}$ & Bersedia \\
\hline 3 & $\begin{array}{l}\text { Ibu Sri Takwadi, Ibu } \\
\text { Susi Wiyadi, Ibu Elly } \\
\text { Sholihan, Ibu Atik } \\
\text { Engkos } \\
\text { Ibu Zubaidah }\end{array}$ & RT 03 & $\begin{array}{c}\text { Pendidikan, } \\
\text { Motivasi,Tata boga, } \\
\text { Tata Busana }\end{array}$ & Bersedia \\
\hline 4 & $\begin{array}{l}\text { Heriarso, Ibu Eko } \\
\text { Ismadi }\end{array}$ & RT 04 & Agama, Akuntansi & Bersedia \\
\hline 5 & $\begin{array}{l}\text { Ibu Seno, Ibu Tri } \\
\text { Taslim }\end{array}$ & RT 05 & Agama, Pendidikan & Bersedia \\
\hline 6 & $\begin{array}{l}\text { Ibu Muzaini, Ibu } \\
\text { Hadirin, Ibu Fadhil, } \\
\text { Ibu Simon, }\end{array}$ & RT 06 & $\begin{array}{c}\text { Tata Boga, Agama, } \\
\text { Kepribadian }\end{array}$ & \\
\hline 7 & Mba Atika & RT 07 & $\begin{array}{c}\text { Motivasi, } \\
\text { kewirausahaan }\end{array}$ & Bersedia \\
\hline 8 & $\begin{array}{l}\text { Ibu Kuntaroko, Ibu } \\
\text { Emita, Ibu Salim, Ibu } \\
\text { Sumridanto }\end{array}$ & RT 08 & Kepribadian, Motivasi & Bersedia \\
\hline 9 & $\begin{array}{l}\text { Ibu Rodiya Iman } \\
\text { Suradi, Ibu Santi } \\
\text { Dadang }\end{array}$ & RT 09 & $\begin{array}{l}\text { Pendidikan, } \\
\text { Ketrampilan, Agama }\end{array}$ & Bersedia \\
\hline 10 & $\begin{array}{l}\text { Ibu Mahmudah } \\
\text { Musahadi }\end{array}$ & RT 10 & Agama, Motivasi & Bersedia \\
\hline 11 & $\begin{array}{l}\text { Ibu Eliya Sutejo, Ibu } \\
\text { Rozin Yusuf }\end{array}$ & RT 11 & Kewirausahaan & Bersedia \\
\hline 12 & Ibu Wawan, Ibu Nono & RT 12 & Pendidikan, Agama & Bersedia \\
\hline
\end{tabular}


Berdasarkan pendataan di atas, potensi yang tercatat dari proses FGD pertama adanya potensi yang cukup banyak dari anggota komunitas RW III Kelurahan Ngaliyan Kecamatan Ngaliyan untuk dapat dimanfaatkan dalam kerangka pengembangan potensi remaja putri di PAP Kafalatul Yatama Yayasan Masjid Attaqwa. Potensi tersebut menjadi potensi yang benar-benar menjanjikan karena semuanya bersedia untuk mentransfer ilmu mereka untuk pengembangan para remaja putri di PAP Kafalatul Yatama Yayasan Masjid Attaqwa Ngaliyan Semarang.

\section{Analisis kebutuhan, kondisi dan potensi}

Setelah menemukan cara mengenai kemungkinan dapat dilaksanakannya program pengabdian di PAP Kafalatul Yatama Yayasan Masjid Attaqwa, maka langkah selanjutnya adalah mengadakan Focus Group Discussion (FGD) untuk melakukan analisis kebutuhan, kondisi dan potensi yang dimiliki oleh PAP Kafalatul Yatama Yayasan Masjid Attaqwa, khususnya pada sasaran atau fokus pengembangan yaitu bidang pendidikan dan ketrampilan. Kegiatan ini dilaksanakan bersama dengan para tokoh masyarakat setempat, pengurus panti dan para pengasuh panti. Dari FGD tersebut ditemukan beberapa hal, yang berupa masalah, kebutuhan, kondisi dan potensi PAP Kafalatul Yatama Yayasan Masjid Attaqwa dan komunitas. Beberapa masalah yang ditemukan adalah: (1) Subyek dampingan adalah remaja putri dengan usia 12-17 tahun dengan pendidikan SMP dan SMA; yatim, dan/atau dhuafa; (2) PAP Kafalatul Yatama Yayasan Masjid Attaqwa telah memiliki agenda kegiatan harian bagi anak asuhnya; (3) Jadwal sekolah yang telah pasti.

Dengan pertimbangan tersebut pendamping harus melakukan rescheduling aktifitas subyek dampingan tanpa mengganggu aktifitas utama mereka bersekolah dan beberapa kegiatan panti yang wajib mereka ikuti.

Pendamping melihat bahwa kemungkinan untuk dapat melakukan pertemuan dengan para remaja di PAP Kafalatul Yatama adalah pada hari Ahad, karena mereka libur. Namun demikian pengasuh memberikan kemungkinan untuk menggunakan salah satu waktu belajar qiroaty. 


\section{Perencanaan program}

Setelah diketemukan beberapa persoalan di atas, maka langkah selanjutnya adalah membuat perencanaan program. Namun untuk menentukan program diperlukan FGD Kedua dengan subyek dampingan untuk menentukan kegiatan yang mereka butuhkan dalam proses pengembangan diri mereka. Oleh karena itu disepakati FGD Kedua dilaksanakan pada tanggal 14 September, yaitu minggu kedua bulan September.

Pertemuan disepakati dan dilaksanakan pada pk. 10.00 - 12.00 dengan agenda need assesment. Kegiatan ini diikuti oleh semua anak asuh PAP Kafalatul Yatama dan pengasuh serta pengurus harian, bidang pendidikan dan bidang kerumahtanggaan. Need assesment dilakukan dalam bentuk sharing forum dengan metode andragogik. Oleh karena itu suasana dibuat secair mungkin, dan pertanyaan yang diajukan adalah: "Andai dalam dua atau tiga bulan ke depan anak-anak memiliki kesempatan untuk menambah ilmu, kira-kira apa ilmu tambahan yang diinginkan? "Jawaban dapat memuat dua pilihan.

Dari dua belas anak, ternyata empat anak menjawab ingin dapat membuat bross dari manik-manik agar dapat dijual; lima anak ingin dapat membuat bunga dari plastik, tiga anak menjawab ingin mahir membuat desain komputer, dan empat ingin dapat berceramah agama, dan enam anak ingin motivasi untuk maju tetap terjaga, dan dua anak ingin dapat membordir.

Secara terbuka anak-anak diajak untuk dapat menentukan prioritas dari daftar keinginan mereka, dengan mempertimbangkan waktu dan sarananya. Setelah mempertimbangkan hal-hal itu, disamping pertimbangan pembentukan integritas seorang muslimah yang kreatif dan produktif, diputuskan bahwa pilihan membordir ditangguhkan ke lain waktu, tanpa menyatakan bahwa pilihan itu tidak penting. Ini penting untuk disampaikan kepada subyek dampingan agar mereka merasa pilihan mereka tetap dihargai.

Selanjutnya dalam FGD Kedua itu juga dilakukan perencanaan kegiatan secara bersama antara subyek binaan, pendamping serta pengasuh dan pengurus PAP Kafalatul Yatama. Kesepakatan yang 
diambil adalah bahwa orientasi pemberdayaan remaja putri di PAP Kafalatul Yatama dibagi menjadi dua tema, yaitu pendidikan dan ketrampilan. Pendidikan meliputi pendidikan agama dan motivasi, dan ketrampilan meliputi pelatihan ketrampilan membuat bros dan bunga dan pelatihan IT. Adapun rencana kegiatannya tampak dalam Tabel 4.

\section{Tabel 4}

\section{Rencana Kegiatan Pemberdayaan Remaja Putri}

$\begin{array}{llcc}\text { No } & \text { Rencana } & \text { Penanggung } & \text { Waktu } \\ & \text { Kegiatan } & \text { Jawab } & \end{array}$

Penanaman Ibu Elly

1 Motivasi sebagai

Muslimah

Sholihan, mba

Ratna

Ibu Hj.

Zubaidah

Heriarso, Ibu Hj. 19 Oktober, 2 November, 16

Hadirin

Ibu Hj. Wid

Wahyono,

Ibu Winarni

Ariyanto

Mas Bima, Mas

Adi
Ahad, 21 September, 5 Oktober, 19 Oktober, 2 November, 16

November 2014 pk. 10.00-12.00
Pelatihan
ketrampilan

4 Pelatihan IT
Ahad, 28 September, 12

Oktober,

26 Oktober, 9 November, 23 November pk. 10.00-12.00
Ahad, 28 September, 12

Oktober,

26 Oktober, 9 November, 23

November 2014, pk 15.30-17.00

Sumber: Analisis Data Primer 
Berdasarkan pemetaan di atas keempat kegiatan secara praktis akan dilaksanakan dalam lima kali pertemuan. Rincian waktunya adalah dua kali pertemuan persiapan, lima kali kegiatan, dan dua kali pertemuan yang merupakan evaluasi akhir dan refleksi.

Hasil kesepakatan ini didiseminasikan kepada anggota komunitas RW III yang akan terlibat dalam kegiatan pemberdayaan remaja putri di PAP Kafalatul Yatama Yayasan Masjid At-Taqwa. Resource persons menyepakati pembagian tanggung jawab dan materi serta waktu yang telah dibahas bersama subyek dampingan, dan memberikan tambahan catatan bahwa dimungkinkan penggantian waktu apabila salah satu pihak, baik subyek dampingan maupun resource persons berhalangan. Waktu yang dipersiapkan adalah Jum'at malam, dengan jadwal semestinya adalah qiroaty/fasholatan. Pilihan Jum'at malam karena materi terkait juga ada di malam lain. Demikian pula Jum'at malam dipilih karena materi sekolah pada hari Sabtu adalah materi-materi yang "ringan".

\section{Pelaksanaan program}

Setelah dilakukan perencaan program pemberdayaan yang disusun secara partisipatif, sebagaimana dipaparkan di atas maka langkah selanjutnya adalah pelaksanaan program pemberdayaan. Pelaksanaan program pemberdayaan disesuaikan dengan ketersediaan waktu yang ada (lihat Tabel 4 di atas). Dengan dasar need assesment di atas maka pelaksanaan karya pengabdian ini dipilah ke dalam empat kegiatan, yaitu: (1) Motivasi dan pembentukan diri; (2) Public speaking (ceramah agama); (3) Pelatihan ketrampilan; dan (4) Pelatihan IT

\section{Monitoring dan evaluasi}

Maksud dari monitoring dan evaluasi dalam pengabdian ini adalah untuk melihat pelaksanaan dan keberhasilan program serta untuk mengevaluasi efektifitas program. Pelaksanaan monitoring dilakukan oleh pelaksana pengabdian dengan cara memantau pelaku, proses, 
metode, dan materi kegiatan sejak dari proses perencanaan hingga akhir pelaksanaan program. Monitoring seperti ini akan dapat mengantisipasi pelaksanaan program yang tidak sesuai dengan orientasi program.

\section{Pendampingan}

Tahap akhir dari pelaksanaan program pengabdian ini adalah melakukan pendampingan kepada sasaran program, yaitu PAP Kafalatul Yatama serta komunitas RW III sebagai komunitas mitra PAP Kafalatul Yatama yang menyediakan resource bagi pelaksanaan program pemberdayaan. Tahapan ini rencananya dilaksanakan juga setelah kegiatan selesai dilaksanakan dengan orientasi keberlangsungan (sustainability).

\section{Pelaksanaan Kegiatan Pengabdian}

Pelaksanaan karya pengabdian dengan tema Pemberdayaan Remaja Putri melalui Kemitraan Komunitas dilaksanakan di PAP Kafalatul Yatama Yayasan Masjid At-Taqwa Kelurahan Ngaliyan Kecamatan Ngaliyan dengan mitra komunitas RW III kelurahan Ngaliyan di mana panti itu berada. Adapun kegiatan pembinaan remaja putri yang dilaksanakan adalah:

1. Pemberian motivasi dan image diri (self-image) sebagai muslimah. Pemberian motivasi dan pembentukan imaje diri sebagai muslimah merupakan materi awal dalam proses pemberdayaan. Alasannya adalah Bina Manusia, merupakan upaya yang pertama dan utama yang harus diperhatikan dalam setiap upaya pemberdayaan masyarakat. Hal ini, dilandasi oleh pemahaman bahwa tujuan pembangunan adalah untuk perbaikan mutu hidup atau kesejahteraan manusia.

2. Pemberian pengetahuan keagamaan untuk didiseminasikan kepada masyarakat. Pemberian materi keagamaan dilakukan sesuai dengan jadwal dan kurikulum yang disepakati antara pemberi materi, pengasuh, pengurus serta pelaksana binaan. Adapun pelaksanaan pemberian materi pengetahuan agama 
ini dalam perjalanannya pernah mengalami pergeseran waktu karena adanya kegiatan sekolah dari subyek dampingan.

Dalam proses pembelajaran, disampaikan oleh resource person yang mendampingi bahwa pada awal proses masih ada beberapa anak yang malu-malu untuk memberikan pendapat, namun dalam perjalanan selanjutnya semua tampak berpartisipasi aktif dalam pembelajaran dan praktek. Pengasuh panti juga sangat penting maknanya dalam memantapkan materi yang diberikan resource person serta memantau keberlanjutan dari proses belajar tersebut.

Hasil dari proses pembelajaran ini ditampilkan dalam perayaan Assyura (10 Muharram), yang dilaksanakan pada tanggal 1 November 2014 bertempat di bangunan PAP Kafalatul Yatama, di Jl. Panembahan Senopati Atas RT 09 RW III Kelurahan Ngaliyan, yang masih dalam proses pembangunan. Dalam kegiatan ini tampak kemampuan remaja putri, anakanak yatim di PAP Kafalatul Yatama tampil sebagai master of ceremony (MC) dan penceramah agama. MC dalam kesempatan itu disampaikan dalam bahasa Arab, Inggris dan bahasa Jawa. Mereka juga menunjukkan kemampuan pembacaan puisi yang mereka susun sendiri. Remaja putri di PAP Kafalatul Yatama dengan percaya diri tinggi menampilkan kemampuan mereka untuk tampil di muka umum.

3. Pemberian ketrampilan membuat bros dan bunga dari bahan plastik. Pelatihan ini memiliki bobot praktek yang sangat tinggi. Selain itu potensi untuk mengasah kreatifitas dan kewirausahaan juga tinggi. Resource person yang menangani bidang ini adalah seorang pengajar bidang ketrampilan dan tata busana sehingga memungkinkan subyek dampingan untuk menggali ilmu dan informasi mengenai ketrampilan. Dalam pertemuan pertama, pengajar telah mempersiapkan material yang dibutuhkan untuk memungkinkan subyek dampingan belajar membuat rangkaian bunga dari bahan plastik. Pilihan membuat bunga dari bahan plastik ini dipilih oleh pengajar dengan pertimbangan mudah 
dibuat sehingga menstimulir subyek dampingan untuk berkreasi lebih lanjut.

Proses pembuatan rangkaian dibuat per tema, yaitu pembuatan rangkaian bunga tulip, mawar, teratai, dan bunga matahari. Setiap pertemuan pengajar memperkenalkan alat dan kebutuhan untuk masing-masing tema, menunjukkan cara pembuatan, dan jika salah seorang anak telah menyelesaikan pekerjaannya maka pengajar mereview dengan cara mengapresiasi hasil pekerjaan dan mengoreksi sisi-sisi yang masih perlu diperbaiki. Tindak lanjut dari setiap sessi pertemuan adalah pekerjaan rumah. Setiap anak mendapatkan tugas untuk membuat bunga yang telah diajarkan dalam jumlah 3-5 tangkai dan akan direview pada pertemuan berikutnya.

Hasil dari proses belajar membuat ketrampilan ini direspon oleh warga dengan cara memesan bunga-bunga tersebut. Pihak pengurus dan pengasuh panti memberikan apresiasi terhadap respon warga tersebut, namun tetap memantau aktifitas anak asuh, yaitu dengan menetapkan agar pembuatan bunga pesanan dikerjakan akhir pekan, atau pada saat senggang. Dalam menentukan harga pesanan, pengasuh berkonsultasi dengan pengajar sehingga harga bunga kompetitif dan mendatangkan keuntungan bagi subyek dampingan. Keuntungan dari penjualan hasil karya ketrampilan ini menjadi tabungan panti yang diperuntukkan bagi pemenuhan berbagai kebutuhan mereka.

4. Pemberian ketrampilan IT. Pemberian ketrampilan IT bagi remaja putri, khususnya subyek dampingan di PAP Kafalatul Yatama dipandang penting untuk era sekarang. Oleh karena itu pemberian materi ini diorientasikan pada pemberian ketrampilan penggunaan IT untuk keperluan pendidikan. Dari tampilan power point tampak adanya kreatifitas subyek dampingan dalam pembuatan sajian presentasi yang mereka buat. 


\section{Kesimpulan}

Dari program karya pengabdian dosen tentang pemberdayaan remaja putrimelalui kemitraan komunitas yang dilaksanakandiPAPKafalatul Yatama Yayasan Masjid At-Taqwa Kelurahan Ngaliyan Kecamatan Ngaliyan Semarang dapat disimpulkan beberapa hal berikut: (1) Penanaman motivasi dan pembentukan imaje diri merupakan aspek terpenting dalam pembinaan pemberdayaan. Oleh karena itu kegiatan ini karena merupakan kegiatan yang memiliki orientasi pembentukan manusia maka tidak mungkin berhenti pada proses pelatihan saja, namun harus berlangsung secara terus menerus hingga tampak perkembangan pada subyek dampingan, bahwa mereka menunjukkan keberdayaan. Setidaknya motivasi untuk mandiri, produktif, dan bertanggung jawab serta berorientasi pada pengabdian ummat tampak. (2) Penanaman kesadaran akan pentingnya dakwah Islam juga penting, dan kemampuan untuk menyampaikan nilai-nilai Islam dalam bentuk public speaking juga bukan upaya mudah. Oleh karena itu pelatihan ini setidaknya merupakan pencetus kesadaran dan minat subyek dampingan mengenai arti penting dakwah Islam itu. Lepas dari itu, subyek dampingan juga diberi wawasan bahwa profesi dakwah Islam juga merupakan profesi yang dapat dipilih. Pemberdayaan remaja putri melalui pemberian kemampuan untuk berdakwah merupakan point penting dalam kerangka dakwah Islam serta pemberdayaan masyarakat. (3) Pemberian ketrampilan berupa handycraft (pembuatan bunga dan bross) merupakan penyiapan subyek dampingan untuk memiliki jiwa kreatif dan produktif. Jiwa kreatif dan produktif akan mendorong remaja putri untuk berfikir mandiri dengan mengembangkan kewirausahaan. Wira usaha merupakan aspek penentu pemberdayaan masyarakat. (4) Pemberian pelatihan IT. Pelatihan IT merupakan pelatihan yang sangat penting bagi pembekalan subyek dampingan. Hal ini karena informasi ditransmisikan melalui berbagai perangkat informasi itu. Oleh karena itu penguasaan IT merupakan hal yang sangat penting, dan proses belajar perlu dilakukan lebih mendalam. 


\section{Daftar Pustaka}

Feisal, Jusuf Amir. 1995. Reorientasi Pendidikan Islam, Jakarta: Gema Insani Press.

Kretzmann JP, McKnight JL. 1990. (Center for Urban Affairs and Policy Research, Neighborhood Innovations Network, Northwestern University) Building communities from the inside out: a path toward finding and mobilizing a community's assets. Chicago (IL): ACTA Publications.

Nasdian, Tonny Fredian. 2014. Pengembangan Masyarakat, Jakarta: Yayasan Pustaka Obor Indonesia.

Partnership: Toward Community Engaged Universities, Forum Publik yang Difasilitasi oleh Organisasi Non-Pemerintah, Seri Publikasi 1.

Pusat Pengembangan Ketahanan Sosial Masyarakat Indonesia, 2002.

Potensi Generasi Muda dalam Mendukung Ketahanan Sosial Masyarakat, Jakarta: Pusat Pengembangan Ketahanan Sosial Masyarakat, Badan Pelatihan dan Pengembangan Sosial, Departemen Sosial RI.

Ranuwiharjo, A. Dahlan, 2000. Gerakan Kaum Intelektual dan Generasi Muda Indonesia, Jakarta: Universitas Nasional Press.

Scottish Community Development Centre on behalf of ommunities Scotland, 1999. The National Standards for Community Engagement

Wrihatnolo, Randy R dan Riant Nugroho Dwidjowijoto, 2007. Manajemen Pemberdayaan: Sebuah Pengantar dan Panduan untuk Pemberdayaan Masyarakat, Jakarta: PT. Elex Media Komputindo. 
Zubaidi, 2013. Pengembangan Masyarakat: Wacana dan Praktik, Jakarta: Penerbit Kencana. 